\title{
The Effect of Plasma Nitriding Process on the Change of Dynamic Parameters of Steel DIN $1654 / 4$
}

David Dobrocky, David Kusmic

Faculty of Military Technology, University of Defence in Brno. Kounicova 65, 66210 Brno. Czech Republic. E-mail: david.dobrocky@unob.cz,david.kusmic@unob.cz

This article describes the effect of selected parameters of plasma nitriding on the change of dynamic parameters of steel DIN 1654/4. Plasma nitriding is currently used in a wide range of technical applications such as a final operation to improve the mechanical properties of components. This experimental investigation is devoted to the analysis of the influence of plasma nitriding on the notch toughness of structural steel DIN 1654/4 (CSN 41 2042.4). The test of the dynamic fracture behaviour of structural steel was carried out using by instrumental Charpy hammer on the plasma nitrided specimens with $V$ and $U$ notch, manufactured according to standard CSN ISO 148-1. The plasma nitriding was implemented at $500\left({ }^{\circ} \mathrm{C}\right)$, process duration $\mathrm{t}=10$ and $20(\mathrm{~h})$ and variable gas mixture ratio of $24 \mathrm{H}_{2}: 8 \mathrm{~N}_{2}(\mathrm{l} / \mathrm{h})$ and $8 \mathrm{H}_{2}: \mathbf{2 4 \mathrm { N } _ { 2 }}(\mathrm{l} / \mathrm{h})$. The test results showed that nitrided steel has become more brittle. However, it was found that for different gas composition, the notch toughness has behaved quite diversely. The values of notch toughness of steel in case of gas ratio $8 \mathrm{H}_{2}: 24 \mathrm{~N}_{2}(\mathrm{l} / \mathrm{h})$ were decreased but for gas ratio $24 \mathrm{H}_{2}: \mathbf{8 N}_{2}$ $(\mathrm{l} / \mathrm{h})$, with extension of time, the notch toughness was slightly increased.

Keywords: Plasma nitriding, Notch toughness

\section{Acknowledgement}

The paper was prepared with the support of the Project for the Development of the Organization and by the Specific research project 2014 of the Department of Mechanical Engineering, UoD "Promoting Research, Science and Inovation in the Field of Engineering".

\section{References}

[1] AKBARI, A., MOHAMMADZADEH, R., TEMPLIER, C., RIVIERE, J. P. (2010). Effect of the initial microstructure on the plasma nitriding behaviour of AISI M2 hihg speed steel. In: Surface and Coatings Technology, vol 204, 2010, pp. 4114-4120.

[2] KADLEC, J., DVOŘÁK, M. (2008). Duplex surface treatment of stainless steel $\mathrm{X}_{12} \mathrm{CrNi}_{18.8}$. In: Strength of Materials, vol. 40, 2008, pp. 118-121.

[3] NOVY, L. (1996). Sample paper. In: Sample Journal, Vol. 3, No. 1, pp. 9 - 15. TTP. Switzerland.

[4] SIRIN, S. Y., SIRIN, K., KALUC, E. (2008). Effect of the ion nitriding surface hardening proces on fatigue behaviour of AISI 4340 steel. In: Materials Characterization, vol. 59, 2008, pp. 351-358.

[5] KUSMIČ, D., DOAN, T., HRUBÝ, V., SVOBODA, E. (2013). Vliv plasmové nitridace na vrubovou houževnatost. In: Transfer 2013, pp. 55-60.

[6] DOBROCKÝ, D., DOAN, T., KUSMIČ, D., HRUBÝ, V. (2014). The Change Of Notch Toughness Parameters Of Steel After Plasma Nitriding. In: ICMT'- 2014, pp. 66-74.

[7] DLOUHÝ, I., HOLZMANN, M. (2001). Vliv povrchového tvrzení na lomové chování ocelí na ozubená kola. In: Cementace a nitridace, Brno, 2001, pp. 155-165.

[8] DIN 1654/4 - Cold heading and extruding steels; Technical delivery conditions for steels quenching and tempering. Deutsches Institut für Normung E. V., 1989.

[9] ČSN ISO 148-1 - Kovové materiály - Zkouška rázem v ohybu metodou Charpy - Část 1: Zkušební metoda, 2009.

[10] ČSN EN ISO 14556 - Ocel - Zkouška rázem v ohybu na kyvadlovém kladivu tyčí Charpy s V-vrubem - Instrumentovaná zkušební metoda, 2001.

[11] DIN 50190-3 - Hardness depth of heat-treated parts; determination of the effective depth of hardening after nitriding. Deutsches Institut für Normung E. V., 1979.

[12] POKORNÝ, Z. (2011). Plazmová nitridace dutin. In: Disertační práce, Brno, 2011, pp. 70-72.

[13] HOLEMÁŘ, A., HRUBÝ, V. (1989). Iontová nitridace v praxi. SNTL, Praha 1989, pp. 178-180. 
[14] PYE, D. (2003). Practical nitriding and ferritic nitrocarburizing. $2^{\text {nd }}$ edition, Ohio: ASM International Materials Park 2003, pp. 127-129.

[15] ALLENSTEIN, A. N., LEPIENSKI, C. M., BUSCHINELLI, A. J. A., BRUNATTO, S. F. (2010). Plasma nitriding using high $\mathrm{H}_{2}$ content gas mixtures for a cavitation erosion resistant steel. In: Applied Surface Science, vol. 277, 2013, pp. 15-24.

[16] LATTNER, M., HOLESOVSKY, F. (2014). Effect of Machining the Load Capacity Notched Components. In: Manufacturing Technology, vol. 14, 2014, pp. 47-50.

[17] MADL, J., RAZEK, V., KOUTNY, V., KAFKA, J. (2013). Surface Integrity in Notches Machining. In: Manufacturing Technology, vol. 13, 2013, pp. 188-193.

[18] MICHNA, Š., NÁPRSTKOVÁ, N (2012). The use of fractography in the analysis of cracking after formed workpiece blank mechanical machining from the AlCuSnBi alloy. In: Manufacturing Technology, vol. 12, 2012, pp. 174-178.

[19] ROSENBERG, G., SINAIOVÁ, I., JUHÁR, L'. (2012). Influence of microstructural heterogeneities on capacity to absorb energy of dual-phase steels. In: Manufacturing Technology, vol. 12, 2012, pp. 222-227. 